\title{
Role of vitamin D-binding protein in isocyanate-induced occupational asthma
}

\author{
Sung-Ho Kim ${ }^{1 \dagger *}$, Gil-Soon $\mathrm{Choi}^{2 *}$, Young-Hee Nam ${ }^{1}$, \\ Joo-Hee $\mathrm{Kim}^{3}$, Gyu-Young Hur ${ }^{4}$, Seung-Hyun Kim ${ }^{1}$, \\ Sang Myun Park ${ }^{5,6}$ and Hae-Sim Park ${ }^{1,6}$ \\ ${ }^{1}$ Department of Allergy and Clinical Immunology \\ Ajou University School of Medicine \\ Suwon 443-721, Korea \\ ${ }^{2}$ Department of Internal Medicine \\ Kosin University College of Medicine \\ Busan 602-703, Korea \\ ${ }^{3}$ Division of Pulmonary \\ Allergy and Critical Care Medicine \\ Department of Medicine \\ Hallym University Sacred Heart Hospital \\ Hallym University College of Medicine \\ Anyang 431-070, Korea \\ ${ }^{4}$ Department of Internal Medicine \\ Korea University College of Medicine \\ Seoul 152-703, Korea \\ ${ }^{5}$ Department of Pharmacology and \\ Chronic Inflammatory \\ Disease Research Center \\ Ajou University School of Medicine \\ Suwon 443-721, Korea \\ ${ }^{6}$ Corresponding authors: Tel, 82-31-219-5063; \\ Fax, 82-31-219-5069; E-mail, sangmyun @ajou.ac.kr (S.M.P.) \\ Tel, 82-31-219-5196; Fax, 82-31-219-5154; \\ E-mail, hspark@ajou.ac.kr (H.S.P.) \\ ${ }^{\dagger}$ Current address: Department of Respiration, the Tianjin First Central \\ Hospital, Tianjin 300192, China \\ *These authors contributed equally to this work. \\ http://dx.doi.org/10.3858/emm.2012.44.5.036
}

Accepted 6 February 2012

Available Online 8 February 2012

Abbreviations: AEC, asymptomatic exposed controls; BALF, bronchoalveolar lavage fluid; HSA, human serum albumin; MDI, diphenyl-methane diisocyanate; NC, unexposed healthy controls; OA, occupational asthma; TDI, toluene diisocyanate; VDBP, vitamin D-binding protein; $1,25(\mathrm{OH})_{2} \mathrm{D}_{3}, 1,25$-dihydroxycholecalciferol; 25(OH) $\mathrm{D}_{3}$, 25-hydroxycholecalciferol

\begin{abstract}
The development of a serological marker for early diagnosis of isocyanate-induced occupational asthma (isocyanate-OA) may improve clinical outcome. Our previous proteomic study found that expression of vitamin D-binding protein (VDBP) was upregulated in the patients with isocyanate-OA. In the present study, we evaluated the clinical relevance of VDBP as a serological marker in screening for isocyanate-OA among exposed workers and its role in the pathogenesis of isocyanate-OA. Three study groups including $61 \mathrm{pa}-$ tients with isocyanate-OA (group I), 180 asymptomatic exposed controls (AECs, group II), 58 unexposed healthy controls (NCs, group III) were enrolled in this study. The baseline serum VDBP level was significantly higher in group I compared with groups II and III. The sensitivity and specificity for predicting the phenotype of isocyanate-OA with VDBP were $69 \%$ and $81 \%$, respectively. The group I subjects with high VDBP $(\geq 311 \mu \mathrm{g} / \mathrm{ml})$ had significantly lower $\mathrm{PC}_{20}$ methacholine levels than did subjects with low VDBP. The in vitro studies showed that TDI suppressed the uptake of VDBP into RLE-6TN cells, which was mediated by the downregulation of megalin, an endocytic receptor of the 25-hydroxycholecalciferol-VDBP complex. Furthermore, toluene diisocyanate (TDI) increased VEGF production and secretion from this epithelial cells by suppression of 1,25-dihydroxycholecalciferol $\left[1,25(\mathrm{OH})_{2} \mathrm{D}_{3}\right]$ production. The findings of this study suggest that the serum VDBP level may be used as a serological marker for the detection of isocyanate-OA among workers exposed to isocyanate. The TDI-induced VEGF production/secretion was reversed by $1,25(\mathrm{OH})_{2} \mathrm{D}_{3}$ treatment, which may provide a potential therapeutic strategy for patients with isocyanate-OA.
\end{abstract}

Keywords: asthma, occupational; biological markers; isocyanates; low density lipoprotein receptor-related protein-2; vascular endothelial growth factorA; vitamin D-binding protein 


\section{Introduction}

Three major isocyanates (toluene diisocyanate, TDI; hexamethylene diisocyanate, HDI; and diphenylmethane diisocyanate, MDI) are highly reactive chemicals used in a variety of chemical manufacturing processes, such as production of polyurethane forms and paints. Isocyanate-induced occupational asthma $(\mathrm{OA})$ is the most frequent cause of OA worldwide (Meredith and Nordman, 1996; Mannino, 2000), with a prevalence rate of around $10 \%$ of exposed workers (Park and Nahm, 1997). Although the specific inhalation challenge test with isocyanate is the gold standard for the confirmative diagnosis of isocyanate-OA, this procedure requires special equipment and is both time and labor intensive. Furthermore, study of the long-term prognosis has shown that more than $50 \%$ of patients with isocyanate-OA have persistent asthma symptoms even after complete avoidance of exposure and treatment with asthma medications (Park and Nahm, 1997). Therefore, early identification of patients may improve the long-term outcome. Previous studies focused on the detection of serum-specific antibodies, which were not sufficiently specific to be used for diagnostic purposes (Cartier et al., 1989; Park et al., 2002; Ye et al., 2006; Wisnewski, 2007; Palikhe et al., 2011).

More recently, proteomic analysis, a process that includes purifying and identifying individual proteins from body fluids, has been used to develop serological markers for diagnosis (Colantonio and Chan, 2005). The results of our previous study using proteomic analysis of patients with diphenyl-methane diisocyanate occupational asthma (MDI-OA) showed upregulation of vitamin D-binding protein (VDBP) expression (Hur et al., 2008a). There has been much interest in the role of the vitamin D axis in lung disease such as asthma, chronic obstructive pulmonary disease and tuber- culosis (Devereux et al., 2009; Janssens et al., 2009; Wilkinson and Lange, 2009; Chishimba et al., 2010), which includes vitamin D and VDBP. Various cytokines, cellular elements, oxidative stress and protease/antiprotease levels affect lung fibroproliferation, remodeling and function, which may be influenced by vitamin D level (Gilbert et al., 2009). Moreover, several previous studies have suggested the active involvement of VEGF in the pathogenesis of isocyanate-OA, which may be mediated by 1,25 -dihydroxycholecalciferol $\left[1,25(\mathrm{OH})_{2}\right.$ $D_{3}$ ], the active form of vitamin D (Nakagawa et al., 2005; Gruber et al., 2008). VEGF (Nakagawa et al., 2005; Gruber et al., 2008), a potent proangiogenic cytokine, plays a central role in angiogenesis, chronic airway inflammation, and airway remodeling in asthma (Voelkel et al., 2006; Walters et al., 2008).

In the present study, the clinical relevance of the serum VDBP level was investigated as a potential candidate marker for screening susceptible subjects exposed to isocyanate. In addition, the mechanism associated with serum VDBP levels and isocyanate exposure was studied.

\section{Results}

\section{Clinical characteristics of the study subjects}

Sixty-one patients with isocyanate-OA (group I), confirmed by positive responses to isocyanate bronchial challenge test, and 180 asymptomatic exposed workers (AECs, group II) from same working environment, including spray-painting and polishing departments of the furniture and musical instrument industries or working in a car upholstery factory and a control group, 58 unexposed healthy controls (NCs, group III) were enrolled in this study. The clinical features of the three study groups are summarized in Table 1 . Atopy was determined by a positive skin test to at least one common inhalant

Table 1. Clinical characteristics of the subjects in the three study groups

\begin{tabular}{lcccc}
\hline & $\begin{array}{c}\text { Group I } \\
(n=61)\end{array}$ & $\begin{array}{c}\text { Group II } \\
(n=180)\end{array}$ & $\begin{array}{c}\text { Group III } \\
(n=58)\end{array}$ & $P$-value \\
\hline Age (years) & $43.48 \pm 8.98$ & $40.98 \pm 8.58$ & $28.80 \pm 6.13^{\ddagger}$ & $<0.001$ \\
Sex (M/F) & $34 / 26$ & $116 / 64$ & $21 / 37$ & 0.002 \\
Working duration (years) & $6.70 \pm 4.56$ & $10.75 \pm 6.70$ & NA & 0.024 \\
Atopy (\%) & $21(34.4 \%)$ & $13(7.2 \%)$ & $5(8.6 \%)$ & $<0.001$ \\
Smoking history (\%) & $12(19.6 \%)$ & $45(25 \%)$ & $1(1.7 \%)$ & 0.321 \\
Total lgE (IU/ml)* & $281 \pm 340$ & $232 \pm 355$ & $82 \pm 104$ & 0.004 \\
FEV $1 \%$ pred) & $85.12 \pm 25.19$ & $100.93 \pm 17.79^{\ddagger}$ & $97.90 \pm 6.75$ & 0.002 \\
\hline
\end{tabular}

Group I, isocyanate-induced occupational asthma; group II, asymptomatic exposed control; group III, unexposed healthy controls; NA, not available. ${ }^{*}$ Values are expressed as means $\pm \mathrm{SD},{ }^{\dagger} P<0.05,{ }^{\ddagger} P<0.05$ (group I vs. group II, or group III). Statistical significance of differences was determined by ANOVA with Bonferroni's correction. 
allergen, including house dust mites, Alternaria, cat fur, dog fur, a tree pollen mixture, a grass pollen mixture, and mugwort and ragweed pollens (Bencard, Bradford, UK). Serum samples from all study subjects were collected at initial examination; all subjects stopped using inhaled or oral steroids for 4 weeks before the study and underwent an interview, chest radiography, and skin prick test. In addition, five patients with isocyanate-OA and seven with AECs had additional blood sampling; the changes in the serum VDBP were observed before and after the isocyanate bronchial challenge tests. This study was reviewed and approved by the Institutional Review Board of Ajou Medical Center, Suwon, Korea, and all subjects gave written informed consent prior to enrollment in the study.

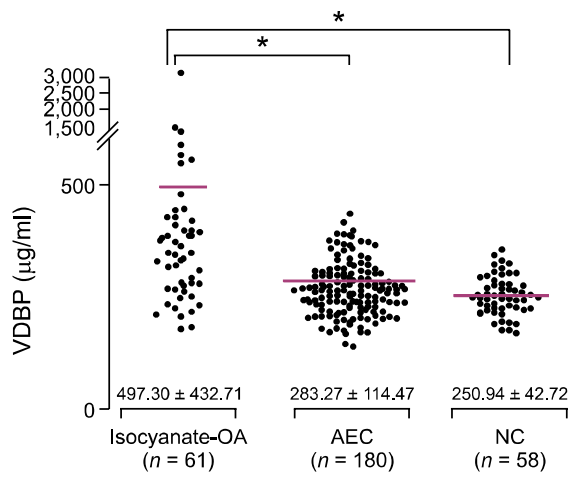

Figure 1. Comparison of serum vitamin D-binding protein (VDBP) levels in the three study groups. group I, isocyanate induced occupational asthma (isocyanate-IA); group II, asymptomatic exposed controls (AEC); group III, unexposed healthy controls (NC). The line indicates the mean value for each group. ${ }^{*} P<0.001$.

\section{Comparison of serum VDBP levels in the three study groups}

To validate the proteins identified by previous proteomic analysis, we compared baseline VDBP levels in the three study groups. Baseline serum levels of VDBP were compared among the three study groups, and the level was significantly higher in group I compared with groups II and III (497.30 $\pm 432.71 \mu \mathrm{g} / \mathrm{ml}, 283.27 \pm 114.47 \mu \mathrm{g} / \mathrm{ml}, 250.94 \pm$ $42.72 \mu \mathrm{g} / \mathrm{ml}$ respectively, $P<0.001$ ); this remained significant after adjusting for age and gender $(P<0.001)$, as shown in Figure 1.

\section{Determination of the optimal cutoff levels for serum VDBP}

To evaluate the diagnostic value of the serum VDBP level for discriminating between group I and II, a receiver operating characteristic (ROC) curve analysis was performed. An optimal cutoff value was selected from the ROC curve to obtain the highest sensitivity and specificity. When the cutoff for VDBP was selected as $\geq 311 \mu \mathrm{g} / \mathrm{ml}$, the sensitivity and specificity were $69 \%$ and $81 \%$, respectively, with 0.765 [95\% confidence interval $(\mathrm{Cl}), 0.688-0.843, P<0.001)]$ as the AUC, with a $55 \%$ positive predictive value and an $88 \%$ negative predictive value.

When the clinical parameters were compared according to the serum VDBP level in group I and II subjects, the subjects with a high serum VDBP level $\geq 311 \mu \mathrm{g} / \mathrm{ml}$ had significantly lower $\mathrm{PC}_{20}$ methacholine levels $(P=0.001)$. The baseline FEV1 level (percent predicted value) tended to be lower in subjects with high serum VDBP levels, although statistical significance was not reached. No significant associations were noted between the serum VDBP level and other demographic and clinical parameters,

Table 2. Comparison of the clinical characteristics between positive and negative groups among the isocyanate-exposed subjects

\begin{tabular}{|c|c|c|c|}
\hline \multirow[b]{2}{*}{ Clinical characteristic } & \multicolumn{2}{|c|}{ Serum VDBP level $(\geq 311 \mu \mathrm{g} / \mathrm{ml})$} & \multirow[b]{2}{*}{$P$-value } \\
\hline & $\begin{array}{c}\text { Higher group } \\
(\geq 311 \mu \mathrm{g} / \mathrm{ml}, n=77)\end{array}$ & $\begin{array}{c}\text { Lower group } \\
(<311 \mu \mathrm{g} / \mathrm{ml}, n=164)\end{array}$ & \\
\hline Age (yrs) & $43.26 \pm 8.71$ & $40.84 \pm 8.66$ & 0.051 \\
\hline $\operatorname{Sex}(M / F)$ & $29 / 17$ & $12 / 11$ & 0.442 \\
\hline Atopy status & $18 / 20$ & $6 / 16$ & 0.174 \\
\hline Disease duration (yrs) & $10.40 \pm 6.73$ & $11.28 \pm 7.70$ & 0.509 \\
\hline Exposed period to TDI (yrs) & $9.50 \pm 5.61$ & $7.92 \pm 6.21$ & 0.395 \\
\hline $\mathrm{FEV}_{1}(\%$ pred $)$ & $87.82 \pm 22.46$ & $97.11 \pm 22.07$ & 0.083 \\
\hline $\mathrm{PC}_{20}$ methacholine $(\mathrm{mg} / \mathrm{ml})$ & $5.10 \pm 8.19$ & $14.80 \pm 11.25$ & 0.001 \\
\hline Total lgE (IU/ml) & $307 \pm 350$ & $224 \pm 346$ & 0.225 \\
\hline
\end{tabular}

Isocyanate-exposed subjects were divided into two groups according to the cutoff value of serum VDBP level: positive ( $\geq 11 \mu \mathrm{g} / \mathrm{ml})$ and negative ( $<311$ $\mu \mathrm{g} / \mathrm{ml}$ ) groups. Statistical significance was evaluated by Student's $t$-test. 
such as age, gender, atopy status, total IgE level, and duration of working (Table 2).

\section{Suppression of FITC-VDBP uptake into RLE-6TN cells by toluene diisocyanate (TDI)}

To examine whether TDI exposure regulates VDBP uptake into RLE-6TN cells, in a rat alveolar epithelial cell line, the characteristics of FITC-VDBP uptake were determined using immunofluorescence analysis as described in the Materials and Methods section. The RLE-6TN cells were incubated in the absence or presence of FITC-VDBP at the indicated doses for $2 \mathrm{~h}$. The results showed a dose-dependent increase in fluorescence intensity, which approached saturation at about $400 \mathrm{nM}$ (Figure 2A). The RLE-6TN cells were incubated with $400 \mathrm{nM}$ FITC-VDBP for the indicated times, and the fluorescence intensity increased in a time-dependent manner, reaching saturation at $120 \mathrm{~min}$ (Figure 2B). Therefore, these conditions were used for further studies. To evaluate the effects of native VDBP on FITC-VDBP uptake into RLE-6TN cells, the cells were preincubated with $0.5,2$, or $4 \mu \mathrm{M}$ native VDBP for $30 \mathrm{~min}$ and then incubated with $400 \mathrm{nM}$ of FITC-VDBP for $2 \mathrm{~h}$. The uptake of FITC-VDBP was suppressed up to $88 \%, 51 \%$, and $27 \%$, respectively, compared with the untreated controls (Figure 2C). In addition, we performed a trypan blue quenching assay to determine whether the measured fluorescence intensity was due to a nonspecific membrane-bound protein. As shown in Figure 2D, when the RLE-6TN cells were treated with or without trypan blue, no significant changes were observed in the fluorescence intensities, suggesting that this FITC-VDBP uptake assay was highly specific.

When the RLE-6TN cells were incubated with 0.5 and $1 \mathrm{mM}$ TDI for $12 \mathrm{~h}$, the FITC-VDBP uptake was decreased by $84.1 \%$ and $52.2 \%$, respectively, compared with dimethyl sulfoxide (DMSO)-treated controls (Figure 3A). Similarly, when the RLE-6TN cells were incubated with $1 \mathrm{mM}$ TDI for 3,6 , or 12 h, its uptake was decreased by $84.9 \%, 74.3 \%$, or $47.6 \%$, respectively, compared with the DMSO-treated controls (Figure 3B), indicating that TDI exposure inhibited VDBP uptake into the RLE-6TN cells in a time- and dose-dependent manner. There was no cytotoxicity associated with TDI under the present experimental conditions (data not shown).

\section{Downregulation of megalin mRNA and protein by TDI treatment in RLE-6TN cells}

VDBP as a form of the 25-hydroxycholecalciferol [25(OH) $\left.\mathrm{D}_{3}\right]$-VDBP complex is taken up into target cells by megalin (Nykjaer et al., 1999). To confirm
A

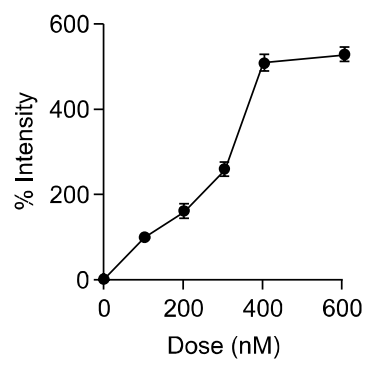

B

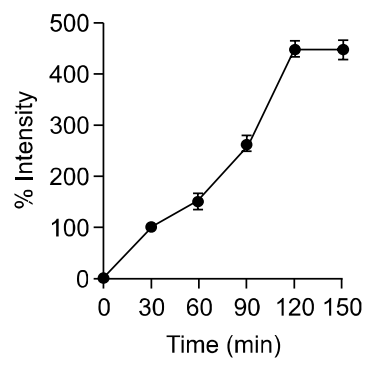

C

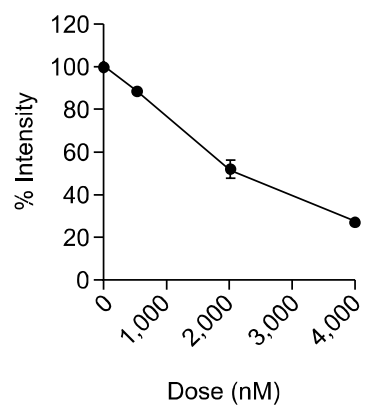

D

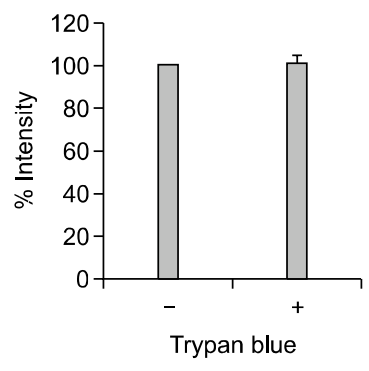

Figure 2. Characteristics of FITC-VDBP uptake. RLE-6TN cells were incubated in serum-free medium at $37^{\circ} \mathrm{C}$ for $2 \mathrm{~h}$ with FITC-VDBP over a concentration range of 100-600 $\mathrm{nM}(\mathrm{A})$, and for a range of times from 30 to 150 min with $400 \mathrm{nM} \mathrm{FITC-VDBP}$ (B). Serum-starved RLE-6TN cells were preincubated with a range of doses of 0.5-4 $\mu \mathrm{M}$ native VDBP for 30 min and then incubated with $400 \mathrm{nM}$ FITC-VDBP at $37^{\circ} \mathrm{C}$ for $2 \mathrm{~h}(\mathrm{C})$. RLE-6TN cells were incubated in serum-free medium at $37^{\circ} \mathrm{C}$ for $2 \mathrm{~h}$ with $400 \mathrm{nM}$ FITC-VDBP. The cells were then washed with PBS and treated with $1.2 \mathrm{mg} / \mathrm{ml}$ trypan blue. Then, FITC intensity was quantified by immunofluorescence assay as described in the Materials and Methods section. Fluorescence intensities of the cells were counted using an image browser, and data are presented as the percent intensity (D). All data are representative of three independent experiments. Values represent the means \pm SEM.

the importance of megalin in VDBP uptake into the RLE-6TN cells, the RLE-6TN cells were preincubated with receptor-associated protein, a known inhibitor of megalin-mediated endocytosis. The uptake of FITC-VDBP was markedly blunted by up to $60 \%$ compared with the untreated controls (Figure 4A), suggesting that megalin mediated endocytic uptake of FITC-VDBP into RLE-6TN cells. Real-time PCR analysis was performed to examine the regulatory effect of TDI on the level of megalin expression. When RLE-6TN cells were incubated with 0.5 and $1 \mathrm{mM}$ TDI for $3 \mathrm{~h}$, the level of megalin mRNA was decreased to $83.8 \%$ and $53.3 \%$ of the control, respectively (Figure 4B). When RLE-6TN cells were incubated with $1 \mathrm{mM}$ TDI for 3,6 , or $9 \mathrm{~h}$, megalin mRNA level was decreased to $53 \%$, $27.3 \%$, or $26 \%$ of the control, respectively (Figure $4 \mathrm{C})$. In addition, Western blotting analysis indicated that megalin expression was downregulated by TDI 
A
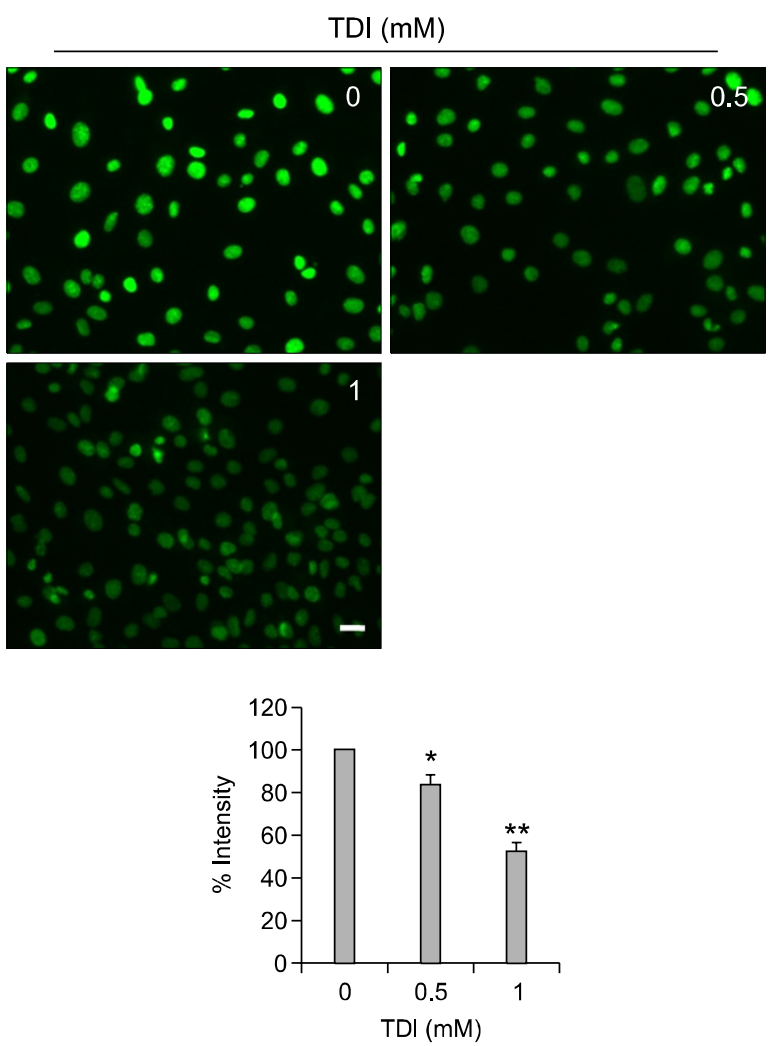
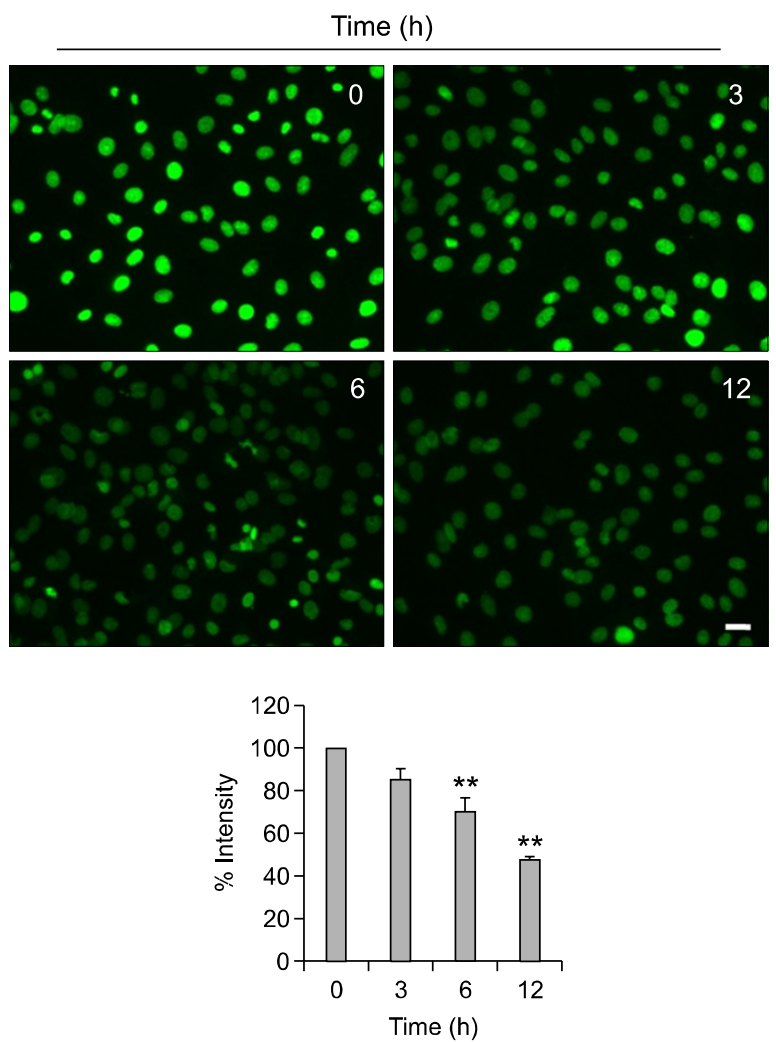

Figure 3. Time- and dose-dependent effects of toluene diisocyanate (TDI) on FITC-VDBP uptake in RLE-6TN cells. RLE-6TN cells were preincubated with $1 \mathrm{mM}$ TDI for the indicated times and then incubated in serum-free medium with $400 \mathrm{nM}$ FITC-VDBP at $37^{\circ} \mathrm{C}$ for $2 \mathrm{~h}$ (A). RLE-6TN cells were preincubated with the indicated doses of TDI for $6 \mathrm{~h}$ and then incubated in serum-free medium with $400 \mathrm{nM}$ FITC-VDBP at $37^{\circ} \mathrm{C}$ for $2 \mathrm{~h}$. Fluorescence was examined using a fluorescence microscope. Scale bar, $20 \mu \mathrm{m}$. In the lower panel, fluorescent intensities of the cells were counted using an image browser, and data are presented as percent intensity (B). All data are representative of three independent experiments. Values represent the means \pm SEM. ${ }^{*} P<0.05,{ }^{* *} P<0.001$ vs. control.

treatment (Figures 4D and 4E).

To evaluate whether TDI inhibits $25(\mathrm{OH}) \mathrm{D}_{3}$ uptake by downregulating megalin expression, RLE-6TN cells were incubated in the absence or presence of TDI (0.5-1 $\mathrm{mM})$ for $6 \mathrm{~h}$ before incubation with $1 \mu \mathrm{M} 25(\mathrm{OH}) \mathrm{D}_{3}$ for $6 \mathrm{~h}$. The level of 1,25-dihydroxycholecalciferol $\left[1,25(\mathrm{OH})_{2} \mathrm{D}_{3}\right]$ production was decreased in a dose-dependent manner, as shown in Figure 5 . These observations suggested that $1,25(\mathrm{OH})_{2} \mathrm{D}_{3}$ mediated its inhibitory action on VEGF secretion via an autocrine loop and that TDI inhibited the intracellular production of $1,25(\mathrm{OH})_{2} \mathrm{D}_{3}$ by inhibiting $25(\mathrm{OH}) \mathrm{D}_{3}$ uptake by downregulating megalin expression.

\section{Increased VEGF production and secretion through suppression of $1,25(\mathrm{OH})_{2} \mathrm{D}_{3}$ production}

The production of $1,25(\mathrm{OH})_{2} \mathrm{D}_{3}$ has been associated with VEGF production and secretion (Nakagawa et al., 2005; Gruber et al., 2008). To examine the possi- bility that TDI regulates VEGF production and secretion by regulating $1,25(\mathrm{OH})_{2} \mathrm{D}_{3}$ production in RLE-6TN cells, the effects of $1,25(\mathrm{OH})_{2} \mathrm{D}_{3}$ on VEGF production were investigated by Western blotting analysis. The cells were incubated with $100 \mathrm{nM} 1,25(\mathrm{OH})_{2} \mathrm{D}_{3}$ for 12,24 , or $48 \mathrm{~h}$, and the resultant expression levels of VEGF were $100 \%$, $52 \%$, and $45 \%$, respectively, compared with the controls (Figure 6A). In addition, when RLE-6TN cells were incubated with 1,10 , or $100 \mathrm{nM}$ $1,25(\mathrm{OH})_{2} \mathrm{D}_{3}$ for $24 \mathrm{~h}$, the resultant VEGF expression levels were $98 \%, 89 \%$, and $58 \%$, respectively, compared with the controls (Figure 6B). These results suggest that $1,25(\mathrm{OH})_{2} \mathrm{D}_{3}$ inhibited VEGF production in the RLE-6TN cells. Next, when RLE-6TN cells were incubated with $1 \mathrm{mM}$ TDI for 3,6 , or $12 \mathrm{~h}$, the expression level of VEGF was increased by $40 \%, 66 \%$, and $180 \%$, respectively, compared with the control (Figure 6C). When the RLE-6TN cells were incubated with 0.5 and $1 \mathrm{mM}$ TDI for $12 \mathrm{~h}$, the level of VEGF expression was in- 
A
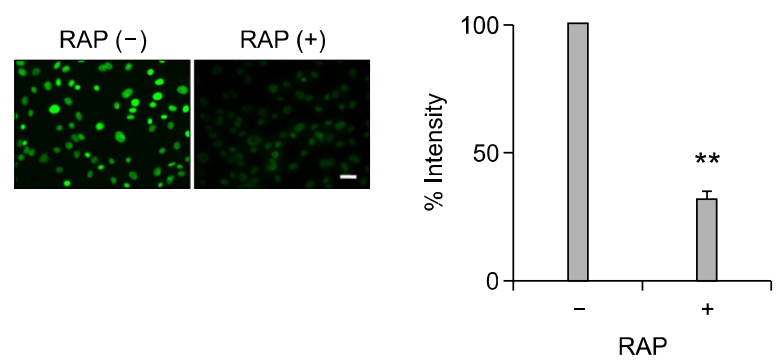

B

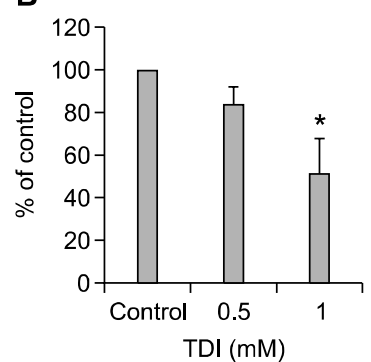

D

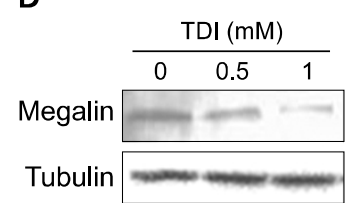

E

C
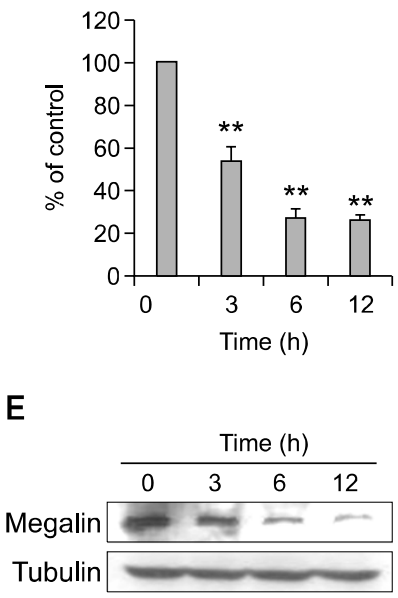

Figure 4. Effects of TDI on megalin expression. RLE-6TN cells were preincubated in serum-free medium with or without $1 \mu \mathrm{M}$ receptor- associated protein (RAP) for $30 \mathrm{~min}$ and then incubated with $400 \mathrm{nM}$ FITC-VDBP at $37^{\circ} \mathrm{C}$ for $2 \mathrm{~h}$. The fluorescence was observed using a fluorescence microscope. Scale bar, $20 \mu \mathrm{m}$. Fluorescence intensities of the cells were counted using an image browser, and data are presented as percent intensity (A). RLE-6TN cells were incubated with the indicated doses of TDI for $3 \mathrm{~h}$, and then real-time PCR was performed (B). RLE-6TN cells were incubated with $1 \mathrm{mM}$ TDI for the indicated times, and then real-time PCR was performed. The values are normalized relative to the GAPDH standard (C). RLE-6TN cells were incubated with the indicated doses of TDI for $12 \mathrm{~h}$ (D). RLE-6TN cells were incubated with 1 $\mathrm{mM}$ TDI for the indicated times, and then Western blotting analysis for megalin was performed. Tubulin was used as a loading control (E). All data are representative of three independent experiments. Values represent the means \pm SEM. ${ }^{*} P<0.05,{ }^{* *} P<0.001$ vs. control.

creased by $54 \%$ and $210 \%$, respectively, compared with the control (Figure 6D). Similar effects of TDI on VEGF secretion were observed on ELISA (Figures 6E and 6F). Furthermore, when the cells were preincubated with $1,25(\mathrm{OH})_{2} \mathrm{D}_{3}$ for $24 \mathrm{~h}$ before treatment with $1 \mathrm{mM}$ TDI for $12 \mathrm{~h}$, VEGF secretion was completely rescued by $100 \mathrm{nM}$ $1,25(\mathrm{OH})_{2} \mathrm{D}_{3}$ (Figure 6F). These findings suggested that TDI exposure increased VEGF production and secretion in RLE-6TN cells by suppression of $1,25(\mathrm{OH})_{2} \mathrm{D}_{3}$ production.

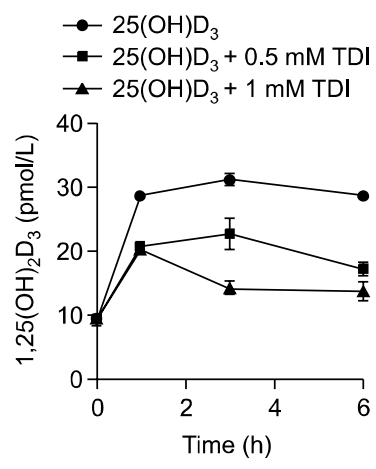

Figure 5. Effects of toluene diisocyanate (TDI) on $1,25(\mathrm{OH})_{2} \mathrm{D}_{3}$ production. RLE-6TN cells were preincubated with the indicated doses of TDI for $6 \mathrm{~h}$ and then incubated with $1 \mu \mathrm{M} 25(\mathrm{OH}) \mathrm{D}_{3}$ for 1,3 , or $6 \mathrm{~h}$. $1,25(\mathrm{OH})_{2} \mathrm{D}_{3}$ in the supernatant was quantified using an enzyme immunoassay kit. Data are representative of two independent experiments. Values represent the means \pm SEM.
A

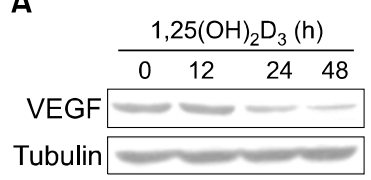

C

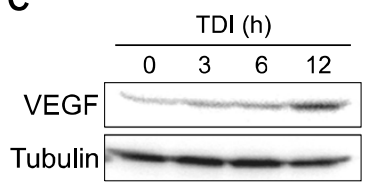

E

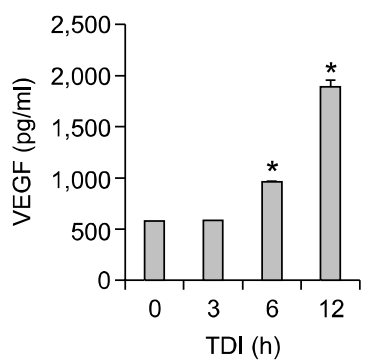

B

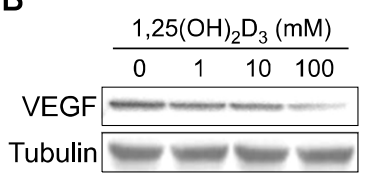

D

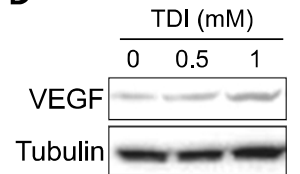

$\mathbf{F}$

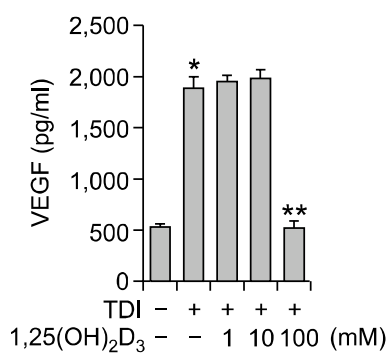

Figure 6. Effects of toluene diisocyanate (TDI) and $1,25(\mathrm{OH})_{2} \mathrm{D}_{3}$ on VEGF production and secretion. RLE-6TN cells were incubated with 100 nM $1,25(\mathrm{OH})_{2} \mathrm{D}_{3}$ alone for the indicated times (A). RLE- $6 \mathrm{TN}$ cells were incubated with the indicated doses of $1,25(\mathrm{OH})_{2} \mathrm{D}_{3}$ alone for $24 \mathrm{~h}$, and then Western blotting analysis for VEGF was performed. Tubulin was used as a loading control (B). RLE-6TN cells were incubated with $1 \mathrm{mM}$ TDI for the indicated times (C). RLE-6TN cells were incubated with the indicated doses of TDI for $12 \mathrm{~h}$, and then Western blotting analysis for VEGF was performed. Tubulin was used as a loading control (D). RLE-6TN cells were incubated with $1 \mathrm{mM}$ TDI for 3, 6, or $12 \mathrm{~h}$, and then the VEGF concentration in each supernatant was quantified using a rat ELISA kit (E). RLE-6TN cells were preincubated with the indicated doses of $1,25(\mathrm{OH})_{2} \mathrm{D}_{3}$ for $24 \mathrm{~h}$ and then incubated with or without $1 \mathrm{mM}$ TDI for 12 $h(F)$. All data are representative of three independent experiments. Values represent the means \pm SEM. ${ }^{*} P<0.001$ vs. TDI(-) and $1,25(\mathrm{OH})_{2} \mathrm{D}_{3}(-) ;{ }^{* *} P<0.001$ vs. TDI(+). 


\section{Discussion}

VDBP, also known as Gc globulin or group-specific component, is a multifunctional serum protein. VDBP has been reported to have a variety of immunological functions, such as in the actin cleavage system, macrophage activation, and chemotaxis of neutrophils, monocytes, and fibroblasts (White and Cooke, 2000; Meier et al., 2006). However, its major function is as a carrier of $25(\mathrm{OH}) \mathrm{D}_{3}$, a major form of circulating vitamin $D$ that is present in the form of the $25(\mathrm{OH}) \mathrm{D}_{3}$-VDBP complex. In our previous study, a proteomic approach with bronchoalveolar lavage fluid (BALF) was used as a screening tool to identify inflammatory mediators involved in the development of isocyanateOA, where VDBP expression was upregulated in BALF of isocyanate-OA patients compared with AECs (Hur et al., 2008a). These findings were consistent with those of previous studies where VDBP was identified in the BALF of asthma patients by proteomic analysis (Noel-Georis et al., 2002; Wu et al., 2005). In the present study, the serum VDBP level was found to be significantly higher in patients with isocyanate-OA compared with controls. Moreover, more severe airway hyperresponsiveness to methacholine was observed in subjects with elevated serum VDBP levels than in those without elevated serum VDBP levels. In addition, the diagnostic value of the serum VDBP level showed significantly increased sensitivity for identifying isocyanate-OA; the sensitivity and specificity for discrimination of isocyanate-OA in exposed workers were $69 \%$ and $81 \%$, respectively. These values were comparable to those of previous studies in which serum-specific antibodies including serum-specific $\lg E$ and $\lg G$ antibodies to TDI-human serum albumin (HAS) conjugate, specific IgG to cytokeratin 19 , and specific $\lg E$ and $\lg$ antibodies to MDI-HSA (Cartier et al., 1989; Choi et al., 2004a; Ye et al., 2006; Wisnewski, 2007; Hur et al., 2008b) were evaluated as potential serological markers for TDI- or MDI-OA. When we measured serum VDBP level in the sera of 45 patients with allergic asthma recruited from Ajou University Hospital, it showed a similar VDBP level to that of group II, but showed a significantly lower level than that of group I (data not shown), indicating that increased serum level of VDBP may be a specific finding for isocyanate-OA, not found in allergic asthma. In the previous study, we reported that the combined levels of serum ferritin and transferrin may be useful as markers for differentiating subjects with MDI-OA among MDI-exposed workers with $71.43 \%$ sensitivity and $85.71 \%$ specificity (Hur et al., 2008a). In this study, we found that measurement of serum
VDBP level is a simple and reproducible method that can be used in larger cohorts of exposed workers with a commercial ELISA kit; it is less expensive to measure one protein than two proteins, i.e., ferritin and transferrin. Based on these findings, the serum VDBP level may be a useful serological marker for differentiating subjects with isocyanate-OA from AEC and for predicting the severity of airway hyperresponsiveness among patients with isocyanate- $O A$.

This is the first study to suggest the potential involvement of VDBP in the pathogenesis of isocyanate-OA. First, we focused on the function of VDBP as a major carrier protein of vitamin D, which is known to be associated with immune modulation of $\mathrm{T}$ helper 2 inflammation and an individual's susceptibility to asthma (Cantorna et al., 2004; Hughes and Norton, 2009). Previous studies demonstrated that the $25(\mathrm{OH}) \mathrm{D}_{3}$-VDBP complex moved compounds to target tissues that were taken up into cells; this process was mediated by an endocytic mechanism via megalin (Nykjaer et al., 1999, 2001; Rowling et al., 2006). Mice lacking megalin were found to develop vitamin $D$ deficiency or rickets due to loss of VDBP and vitamin D metabolites (Dusso et al., 2005), indicating that megalin is a major endocytic receptor for the uptake of vitamin $D$. Once taken up into the target cells, $25(\mathrm{OH}) \mathrm{D}_{3}$ was dissociated from VDBP and metabolized to $1,25(\mathrm{OH})_{2} \mathrm{D}_{3}$. Megalin is expressed not only in the kidney cells (Nykjaer et al., 1999; Hosojima et al., 2009) but also in the alveolar epithelial cells (Lundgren et al., 1997). The results of the present study showed that TDI exposure suppresses VDBP and $25(\mathrm{OH}) \mathrm{D}_{3}$ uptake along with downregulating megalin expression in a dose- and time-dependent manner in RLE-6TN cells. These results suggest that TDI exposure may lead to higher VDBP levels in exposed tissue, such as BALF, in susceptible workers by suppressing megalin expression in lung alveolar cells.

It is postulated that VEGF could act as an angiogenic factor that is capable of altering subepithelial vascularity, which would increase pulmonary microvascular permeability, thus enhancing airway inflammation and remodeling in patients with TDIand MDI-OA (Weyel and Schaffer, 1985; Mapp et al., 1988; Nabe et al., 2005). In addition, the VEGF level increased in the BALF after TDI challenge in a murine model of TDI-OA (Lee et al., 2002) and in the induced sputum of TDI-induced asthma patients. (Choi et al., 2004b) VEGF appears to play an important role, at least in part, in the pathogenesis of isocyanate-OA (Weyel and Schaffer, 1985; Mapp et al., 1988; Nabe et al., 2005). Recently, $1,25(\mathrm{OH})_{2} \mathrm{D}_{3}$ has been reported to have 
a negative regulatory effect on VEGF production and secretion (Nakagawa et al., 2005; Gruber et al., 2008). The mechanism by which $1,25(\mathrm{OH})_{2} \mathrm{D}_{3}$ regulates VEGF expression and secretion is currently unclear. However, a few mechanisms have been suggested. First, it may be related to the rapid induction of non-transcriptional responses, which may occur via activation of transmembrane signal-transduction pathways, such as protein kinase C, phosphatidylinositol 3-kinase/Akt, and p42/p44 MAP kinase (Nemere et al., 1998; Ma et al., 2006; Gruber et al., 2008), where all of the kinases were closely associated with VEGF expression (Berra et al., 2000; Aida et al., 2005). 1,25(OH $)_{2} \mathrm{D}_{3}$ induced rapid and sustained activation of phosphatidylinositol 3-kinase/Akt, this effect was nongenomic (Ma et al., 2006). Swain et al. reported $1,25(\mathrm{OH})_{2} \mathrm{D}_{3}$ may regulate phopholipase $\mathrm{C}$ production by the cells, which, in turn, may modulate signal transduction by receptors with tyrosine kinase activity, including VEGF. (Swain et al., 1992). Second, $1,25(\mathrm{OH})_{2} \mathrm{D}_{3}$ may modulate the expression of growth factor receptors (Koga et al., 1988). Finally, growth factors could modulate the expression of the nuclear vitamin D receptor (Haussler et al., 1998). The central role of vitamin $D$ receptor in the biology of vitamin $D$ action has been known at the molecular level. In the present study, TDI exposure increased VEGF production and secretion from RLE-6TN cells by suppression of $1,25(\mathrm{OH})_{2} \mathrm{D}_{3}$ production, which was reversed by $1,25(\mathrm{OH})_{2} \mathrm{D}_{3}$ treatment. This is the first study to demonstrate the regulatory effects of $1,25(\mathrm{OH})_{2} \mathrm{D}_{3}$ on TDI-induced VEGF production and secretion. The administration of $1,25(\mathrm{OH})_{2} \mathrm{D}_{3}$ may reduce VEGF-induced airway inflammation in patients with isocyanate-OA. Although further studies are needed to elucidate the mechanisms by which TDI decreases megalin expression and $1,25(\mathrm{OH})_{2} \mathrm{D}_{3}$ decreases VEGF production and secretion, this information may provide insight to facilitate the development of new therapeutic strategies for the treatment of isocyanate-OA.

In conclusion, the results of this study demonstrated that the measurement of serum VDBP levels may be a useful serological marker for the early detection of isocyanate-OA among exposed workers. TDIinduced VEGF production/secretion may be reversed by $1,25(\mathrm{OH})_{2} \mathrm{D}_{3}$ treatment, which may provide a potential therapeutic strategy for isocyanateOA.

\section{Methods}

\section{Bronchial challenge testing with methacholine and isocyanate}

All subjects with asthma underwent lung function measure- ment and inhalation challenge tests with methacholine and isocyanate. Airway responsiveness to methacholine was tested using the five-breath dosimeter protocol, as described previously (Park et al., 1999; Ye et al., 2006). The methacholine $\mathrm{PC}_{20}$ level was determined by interpolation from the dose-response curve. The isocyanate (TDI or MDI) bronchial challenge tests were performed according to the method described previously (Park et al., 1999; Ye et al., 2006).

\section{Measurement of VDBP levels in the sera}

The level of VDBP in sera was measured using a commercially available ELISA kit (Immunodiagnostik AG, Bensheim, Germany) according to the manufacturer's instructions. The serum samples were diluted 1:10000 just before the assay to ensure that the measured values were within the optimal range of the standard curve. The inter- and intra-assay variations of this ELISA kit were under $19.3 \%$ and $5.0 \%$, respectively.

\section{Cell culture and treatment with TDI}

The rat alveolar epithelial cell line RLE-6TN, which was characterized and found to be similar to alveolar type 2 cells, including the expression of cytokeratin 19 (Paine et al., 1988; Driscoll et al., 1995), was purchased from the American Type Culture Collection (Manassas, VA). The cells were cultured in D-MEM/F-12 containing $10 \%$ FBS, $100 \mathrm{IU} / \mathrm{ml}$ penicillin, and $100 \mu \mathrm{g} / \mathrm{ml}$ streptomycin, in an atmosphere of $5 \% \mathrm{CO}_{2}$ and $95 \%$ air at $37^{\circ} \mathrm{C}$. TDI (Sigma, St. Louis, MO) was thawed at $37^{\circ} \mathrm{C}$, then diluted in DMSO $(1: 20, v / v)$. When the cells were treated with TDI, controls were treated with an equivalent amount of DMSO; the final DMSO concentration was less than $0.3 \%(\mathrm{v} / \mathrm{v})$.

\section{Real-time reverse transcriptase-PCR}

Total RNA was isolated from RLE-6TN cells using an Easy-BLUE Total RNA Extraction Kit (iNtRON Biotechnologies, Seoul, Korea) after exposure to $0.5-1 \mathrm{mM}$ TDI for 3-12 $\mathrm{h}$. Total RNA $(2 \mu \mathrm{g})$ was reverse transcribed using the oligo (dT) primer and MMLV reverse transcriptase (Promega, Madison, $\mathrm{WI}$ ) at $42^{\circ} \mathrm{C}$ for $90 \mathrm{~min}$. Real-time PCR was performed using an $\mathrm{ABI}$ Prism 7500 instrument according to the manufacturer's instructions (Applied Biosystems, Foster City, CA). The following primer pairs were used: megalin, forward $5^{\prime}$-TGGAATCTCCCTTGATCCTG-3' and reverse, 5'-TGTTGCTGCCATCAGTCTTC-3'; and GAPDH, forward 5'- GGCCAAAAGGGTCATCATC-3' and reverse, 5'-GTGATGGCATGGACTGTGG-3'. After an initial hot start for $10 \mathrm{~min}$, amplification was performed for 40 cycles consisting of denaturation for $10 \mathrm{~s}$ at $94^{\circ} \mathrm{C}$, annealing for $30 \mathrm{~s}$ at $56^{\circ} \mathrm{C}$, and extension for $40 \mathrm{~s}$ at $72^{\circ} \mathrm{C}$. The amplification kinetics was recorded as sigmoid progress curves for which fluorescence was plotted against the number of amplification cycles. The threshold cycle number (CT) was used to define the initial amount of each template. The CT was the first cycle for which a detectable fluorescent signal was observed. The mRNA expression levels were determined and compared with the GAPDH standard. 


\section{Preparation of FITC-VDBP conjugate and immunofluorescence staining}

VDBP was purchased from Calbiochem (La Jolla, CA). FITC-VDBP conjugate was prepared using a Pierce FITC antibody labeling kit according to the manufacturer's instructions (Pierce, Rockford, IL). For the in vitro VDBP-uptake studies, aliquots of $2 \times 10^{4}$ of the RLE-6TN cells were seeded on cover slips in 24-well plates. The next day, the cells were preincubated with or without 0.5-1 mM TDI for 3-12 h, washed twice with PBS, and incubated with 400 nM FITC-VDBP conjugate in serum-free medium for $2 \mathrm{~h}$. For competition assay, the cells were incubated in the absence or presence of the indicated doses of native VDBP for $30 \mathrm{~min}$ and then incubated with $400 \mathrm{nM}$ FITC-VDBP for $2 \mathrm{~h}$. For the trypan blue quenching assay, the cells were incubated with FITC-VDBP conjugate and then incubated with or without $1.2 \mathrm{mg} / \mathrm{ml}$ trypan blue (Sigma, St. Louis, $\mathrm{MO})$ for $15 \mathrm{~min}$ to quench the extracellular fluorescence signal. After washing, the cells were fixed with $4 \%$ paraformaldehyde and observed under a fluorescence microscope (Carl Zeiss, Jena, Germany). More than 30 cells per field were randomly selected from each of five fields in three separate experiments, and the fluorescence intensity was determined by processing FITC images at the cellular level; the percent intensity was calculated as the mean fluorescence intensity of the sample divided by that of the control.

\section{Western blotting analysis}

Cell lysates were separated by $5 \%$ (for megalin) or $10 \%$ SDS-PAGE. The membranes were blocked in blocking solution ( $5 \%$ nonfat dried milk in PBS) for $1 \mathrm{~h}$ at room temperature and then probed with anti-megalin, anti-VEGF (Santa Cruz Technology, Santa Cruz, CA), and anti-tubulin (Sigma) antibodies for $1 \mathrm{~h}$ at room temperature. After washing three times with PBS containing $0.1 \%$ Tween-20 (PBS-T), the membranes were incubated with secondary antibodies (Cell Signaling Technology, Beverly, MA) for $1 \mathrm{~h}$ at room temperature. After washing an additional three times in PBS-T, the membranes were developed using an ECL solution (Pierce, Rockford, IL) and exposed to Chemidoc XRS Gel Documentation System (Bio-Rad, Hercules, CA).

\section{Measurement of $1,25(\mathrm{OH})_{2} \mathrm{D}_{3}$ production and VEGF secretion}

RLE-6TN cells were incubated with $1 \mathrm{mM}$ TDI for $6 \mathrm{~h}$ and then further incubated with $1 \mu \mathrm{M} 25(\mathrm{OH})_{2} \mathrm{D}_{3}$ (Sigma) for 1 , 3 , or $6 \mathrm{~h}$. $1,25(\mathrm{OH})_{2} \mathrm{D}_{3}$ in the supernatant was quantified using an enzyme immunoassay kit for $1,25(\mathrm{OH})_{2} \mathrm{D}_{3}$ (Immunodiagnostic Systems, Boldon, UK) according to the manufacturer's instructions. For detecting VEGF, the RLE-6TN cells were incubated with $1 \mathrm{mM}$ TDI for 3,6 , or $12 \mathrm{~h}$ or incubated with 1,10 , or $100 \mathrm{nM} 1,25(\mathrm{OH})_{2} \mathrm{D}_{3}$ for $24 \mathrm{~h}$ before treatment with $1 \mathrm{mM}$ TDI for $12 \mathrm{~h}$. The VEGF level in the supernatant was quantified using an ELISA kit for rat VEGF (Invitrogen, Camarillo, CA) according to the manufacturer's instructions.

\section{Statistical Analyses}

All values are expressed as the means \pm SEM, unless otherwise stated. The significance of differences among groups was evaluated by the Student's $t$-test and $\chi^{2}$ test. Comparison of the serum VDBP in each group was performed by ANOVA with Bonferroni's correction. Wilcoxon's test was used to compare VDBP levels in sera obtained before and after isocyanate bronchial challenge tests within the groups. A ROC curve was constructed to evaluate the diagnostic value of the serum VDBP for discrimination between isocyanate-OA and AECs, and the AUC with $95 \%$ $\mathrm{Cl}$ was computed. Sensitivity and specificity were calculated according to the identified optimal cutoffs. All analyses were carried out using SPSS 13.0 software (SPSS Inc., Chicago, IL). In all analyses, $P<0.05$ was taken to indicate statistical significance.

\section{Acknowledgements}

This work was supported in part by a Korean Science and Engineering Foundation (KOSEF) grant (MEST, 200900786746 to H. S. P.) and a Korea Science and Engineering Foundation through Chronic Inflammatory Disease Research Center Ajou University Grant (R132003-019 to S. M. P.) funded by the Korean government.

\section{References}

Aida M, Irie T, Aida T, Tachikawa T. Expression of protein kinases $C$ betal, betall, and VEGF during the differentiation of enamel epithelium in tooth development. J Dent Res 2005;84:234-9

Berra E, Pages G, Pouyssegur J. MAP kinases and hypoxia in the control of VEGF expression. Cancer Metastasis Rev 2000;19:139-45

Cantorna MT, Zhu Y, Froicu M, Wittke A. Vitamin D status, 1,25-dihydroxyvitamin D3, and the immune system. Am J Clin Nutr 2004;80:1717S-20S

Cartier A, Grammer L, Malo JL, Lagier F, Ghezzo H, Harris $\mathrm{K}$, et al. Specific serum antibodies against isocyanates: association with occupational asthma. J Allergy Clin Immunol 1989;84:507-14

Chishimba L, Thickett D, Stockley R, Wood A. The vitamin $\mathrm{D}$ axis in the lung: a key role for vitamin D-binding protein. Thorax 2010;65:456-62

Choi JH, Nahm DH, Kim SH, Kim YS, Suh CH, Park HS, Ahn SW. Increased levels of IgG to cytokeratin 19 in sera of patients with toluene diisocyanate-induced asthma. Ann Allergy Asthma Immunol 2004a;93:293-8

Choi JH, Suh YJ, Lee SK, Suh CH, Nahm DH, Park HS. Acute and chronic changes of vascular endothelial growth factor (VEGF) in induced sputum of toluene diisocyanate (TDI)-induced asthma patients. J Korean Med Sci 2004b;19: 359-63

Colantonio DA, Chan DW. The clinical application of proteomics. Clin Chim Acta 2005;357:151-8 
Devereux G, Macdonald H, Hawrylowicz C. Vitamin D and Asthma: Time for Intervention? Am J Respir Crit Care Med 2009;179:739-40

Driscoll KE, Carter JM, lype PT, Kumari HL, Crosby LL, Aardema MJ, Isfort RJ, Cody D, Chestnut MH, Burns JL, Leboeuf RA. Establishment of immortalized alveolar type II epithelial cell lines from adult rats. In Vitro Cell Dev Biol Anim 1995;31:516-27

Dusso AS, Brown AJ, Slatopolsky E. Vitamin D. Am J Physiol Renal Physiol 2005;289:F8-28

Gilbert CR, Arum SM, Smith CM. Vitamin D deficiency and chronic lung disease. Can Respir J 2009;16:75-80

Gruber HE, Hoelscher G, Ingram JA, Chow Y, Loeffler B, Hanley EN Jr. 1,25(OH)2-vitamin D3 inhibits proliferation and decreases production of monocyte chemoattractant protein-1, thrombopoietin, VEGF, and angiogenin by human annulus cells in vitro. Spine (Phila Pa 1976) 2008;33:755-65

Haussler MR, Whitfield GK, Haussler CA, Hsieh JC, Thompson PD, Selznick SH, Dominguez CE, Jurutka PW. The nuclear vitamin $D$ receptor: biological and molecular regulatory properties revealed. J Bone Miner Res 1998;13: 325-49

Hosojima M, Sato $H$, Yamamoto K, Kaseda R, Soma T, Kobayashi A, Suzuki A, Kabasawa H, Takeyama A, Ikuyam K, lino N, Nishiyama A, Thekkumkara TJ, Takeda T, Suzuki Y, Gejyo F, Saito A. Regulation of megalin expression in cultured proximal tubule cells by angiotensin II type 1A receptor- and insulin-mediated signaling cross talk. Endocrinology 2009;150:871-8

Hughes DA, Norton R. Vitamin D and respiratory health. Clin Exp Immunol 2009;158:20-5

Hur GY, Choi GS, Sheen SS, Lee HY, Park HJ, Choi SJ, Ye YM, Park HS. Serum ferritin and transferrin levels as serologic markers of methylene diphenyl diisocyanateinduced occupational asthma. J Allergy Clin Immunol 2008a;122:774-80

Hur GY, Koh DH, Choi GS, Park HJ, Choi SJ, Ye YM, Kim KS, Park HS. Clinical and immunologic findings of methylene diphenyl diisocyanate-induced occupational asthma in a car upholstery factory. Clin Exp Allergy 2008b;38:586-93

Janssens W, Lehouck A, Carremans C, Bouillon R, Mathieu $C$, Decramer M. Vitamin D beyond bones in chronic obstructive pulmonary disease: time to act. Am J Respir Crit Care Med 2009;179:630-6

Koga M, Eisman JA, Sutherland RL. Regulation of epidermal growth factor receptor levels by 1, 25-dihydroxyvitamin D3 in human breast cancer cells. Cancer Res 1988;48:2734-9

Lee YC, Kwak YG, Song $\mathrm{CH}$. Contribution of vascular endothelial growth factor to airway hyperresponsiveness and inflammation in a murine model of toluene diisocyanateinduced asthma. J Immunol 2002;168:3595-600

Lundgren S, Carling T, Hjalm G, Juhlin C, Rastad J, Pihlgren U, Rask L, Akerstrom G, Hellman P. Tissue distribution of human gp330/megalin, a putative $\mathrm{Ca}^{2+}$-sensing protein. $\mathrm{J}$ Histochem Cytochem 1997;45:383-92

Ma Y, Yu WD, Kong RX, Trump DL, Johnson CS. Role of non- genomic activation of phosphatidylinositol 3-kinase/Akt and mitogen-activated protein kinase/extracellular signal-regulated kinase kinase/extracellular signal-regulated kinase 1/2 pathways in 1,25D3-mediated apoptosis in squamous cell carcinoma cells. Cancer Res 2006;66:8131-8

Mannino DM. How much asthma is occupationally related? Occup Med 2000;15:359-68

Mapp CE, Corona PC, De Marzo N, Fabbri L. Persistent asthma due to isocyanates. A follow-up study of subjects with occupational asthma due to toluene diisocyanate (TDI). Am Rev Respir Dis 1988;137:1326-9

Meier U, Gressner O, Lammert F, Gressner AM. Gc-globulin: roles in response to injury. Clin Chem 2006;52:1247-53

Meredith S, Nordman H. Occupational asthma: measures of frequency from four countries. Thorax 1996;51:435-40

Nabe T, Yamauchi K, Shinjo Y, Niwa T, Imoto K, Koda A, Kohno S. Delayed-type asthmatic response induced by repeated intratracheal exposure to toluene-2,4-diisocyanate in guinea pigs. Int Arch Allergy Immunol 2005;137:115-24

Nakagawa K, Kawaura A, Kato S, Takeda E, Okano T. 1 alpha,25-Dihydroxyvitamin $\mathrm{D}(3)$ is a preventive factor in the metastasis of lung cancer. Carcinogenesis 2005;26:429-40

Nemere I, Schwartz Z, Pedrozo H, Sylvia VL, Dean DD, Boyan BD. Identification of a membrane receptor for 1,25-dihydroxyvitamin D3 which mediates rapid activation of protein kinase C. J Bone Miner Res 1998;13:1353-9

Noel-Georis I, Bernard A, Falmagne P, Wattiez R. Database of bronchoalveolar lavage fluid proteins. J Chromatogr B Analyt Technol Biomed Life Sci 2002;771:221-36

Nykjaer A, Dragun D, Walther D, Vorum H, Jacobsen C, Herz $\mathrm{J}$, Melsen F, Christensen El, Willnow TE. An endocytic pathway essential for renal uptake and activation of the steroid 25-(OH) vitamin D3. Cell 1999;96:507-15

Nykjaer A, Fyfe JC, Kozyraki R, Leheste JR, Jacobsen C, Nielsen MS, Verroust PJ, Aminoff M, de la Chapelle $A$ Moestrup SK, Ray R, Gliemann J, Willnow TE, Christensen El. Cubilin dysfunction causes abnormal metabolism of the steroid hormone $25(\mathrm{OH})$ vitamin $\mathrm{D}(3)$. Proc Natl Acad Sci USA 2001;98:13895-900

Paine R, Ben-Ze'ev A, Farmer SR, Brody JS. The pattern of cytokeratin synthesis is a marker of type 2 cell differentiation in adult and maturing fetal lung alveolar cells. Dev Biol 1988;129:505-15

Palikhe NS, Kim JH, Park HS. Biomarkers predicting isocyanate-induced asthma. Allergy Asthma Immunol Res 2011;3:21-6

Park HS, Nahm DH. Prognostic factors for toluene diisocyanate-induced occupational asthma after removal from exposure. Clin Exp Allergy 1997;27:1145-50

Park HS, Kim HY, Nahm DH, Son JW, Kim YY. Specific IgG, but not specific lgE, antibodies to toluene diisocyanate-human serum albumin conjugate are associated with toluene diisocyanate bronchoprovocation test results. J Allergy Clin Immunol 1999;104:847-51

Park HS, Lee SK, Kim HY, Nahm DH, Kim SS. Specific 
immunoglobulin $E$ and immunoglobulin $G$ antibodies to toluene diisocyanate-human serum albumin conjugate: useful markers for predicting long-term prognosis in toluene diisocyanate-induced asthma. Clin Exp Allergy 2002;32:551-5

Rowling MJ, Kemmis CM, Taffany DA, Welsh J. Megalin-mediated endocytosis of vitamin $D$ binding protein correlates with 25-hydroxycholecalciferol actions in human mammary cells. J Nutr 2006;136:2754-9

Swain LD, Schwartz Z, Boyan BD. 1, 25-(OH) 2D3 and 24, $25-(\mathrm{OH}) 2 \mathrm{D} 3$ regulation of arachidonic acid turnover in chondrocyte cultures is cell maturation-specific and may involve direct effects on phospholipase A2. Biochim Biophys Acta 1992;1136:45-51

Voelkel NF, Vandivier RW, Tuder RM. Vascular endothelial growth factor in the lung. Am J Physiol Lung Cell Mol Physiol 2006;290:L209-21

Walters EH, Soltani A, Reid DW, Ward C. Vascular remodelling in asthma. Curr Opin Allergy Clin Immunol 2008;8:39-43

Weyel DA, Schaffer RB. Pulmonary and sensory irritation of diphenylmethane-4,4'- and dicyclohexylmethane-4,4'-diisocyanate. Toxicol Appl Pharmacol 1985;77:427-33

White $\mathrm{P}$, Cooke $\mathrm{N}$. The multifunctional properties and characteristics of vitamin D-binding protein. Trends Endocrinol Metab 2000;11:320-7

Wilkinson RJ, Lange C. Vitamin D and tuberculosis: new light on a potent biologic therapy? Am J Respir Crit Care Med 2009;179:740-2

Wisnewski AV. Developments in laboratory diagnostics for isocyanate asthma. Curr Opin Allergy Clin Immunol 2007;7: 138-45

Wu J, Kobayashi M, Sousa EA, Liu W, Cai J, Goldman SJ, Dorner AJ, Projan SJ, Kavuru MS, Qiu Y, Thomassen MJ. Differential proteomic analysis of bronchoalveolar lavage fluid in asthmatics following segmental antigen challenge. Mol Cell Proteomics 2005;4:1251-64

Ye YM, Kim CW, Kim HR, Kim HM, Suh CH, Nahm DH, Park HS, Redlich CA, Wisnewski AV. Biophysical determinants of toluene diisocyanate antigenicity associated with exposure and asthma. J Allergy Clin Immunol 2006;118:885-91 